\title{
Stress mitigation strategies of plant growth-promoting rhizo- bacteria: Plant growth-promoting rhizobacteria mechanisms
}

\section{Vriti Sharma, Aakriti Singh, Diksha Sharma, Aashima Sharma, Sarika Phogat, Navjyoti Chakraborty, Sayan Chat- terjee \& Ram Singh Purty ${ }^{\star}$}

University School of Biotechnology, Guru Gobind Singh Indraprastha University, Sector-16C, Dwarka, New Delhi-110 078, India

`Email: rspurty@ipu.ac.in

\section{OPEN ACCESS}

\section{ARTICLE HISTORY}

Received: 12 October 2021

Accepted: 25 December 2021

Available online

Version 1.0: 12 February 2022

\section{Check for updates}

\section{Additional information}

Peer review: Publisher thanks Sectional Editor and the other anonymous reviewers for their contribution to the peer review of this work.

Reprints \& permissions information is available at https://horizonepublishing.com/ journals/index.php/PST/open_access_policy

Publisher's Note: Horizon e-Publishing Group remains neutral with regard to jurisdictional claims in published maps and institutional affiliations.

\begin{abstract}
Indexing: Plant Science Today, published by Horizon e-Publishing Group, is covered by Scopus, Web of Science, BIOSIS Previews, Clarivate Analytics, etc. See https:// horizonepublishing.com/journals/index.php/ PST/indexing_abstracting
\end{abstract}

Copyright: $\odot$ The Author(s). This is an openaccess article distributed under the terms of the Creative Commons Attribution License, which permits unrestricted use, distribution and reproduction in any medium, provided the original author and source are credited (https://creativecommons.org/licenses/ by/4.0/)

\section{CITE THIS ARTICLE}

Sharma V, Singh A, Sharma D, Sharma A Phogat S, Chakraborty N, Chatterjee S, Purty RS. Stress mitigation strategies of plant growth-promoting rhizobacteria: Plant growth-promoting rhizobacteria mechanisms . Plant Science Today 2022;8(sp1):2532. https://doi.org/10.14719/pst.1543

\begin{abstract}
One of the major challenges that the world is facing currently is the inadequate amount of food production with high nutrient content in accordance with the increase in population size. Moreover, availability of cultivable area with fertile soil is reducing day by day owing to ever increasing population. Further, water scarcity and expensive agricultural equipment have led to the use of agrochemicals and untreated water. Excessive use of chemical fertilizers to increase crop yield have resulted in deleterious effects on the environment, health and economy, which can be overcome to a great extent by employing biological fertilizers. There are various microbes that grows in the rhizospheric region of plants known as plant growth-promoting rhizobacteria (PGPR). PGPR act by direct and indirect modes to stimulate plant growth and improve stress reduction in plants. PGPRs are used for potential agriculture practices having a wide range of benefits like increase in nutrients content, healthy growth of crops, production of phytohormones, prevention from heavy metal stress conditions and increase in crop yield. This review reports recent studies in crop improvement strategies using PGPR and describes the mechanisms involved. The potential mechanisms of PGPR and its allies pave the way for sustainable development towards agriculture and commercialization of potential bacteria.
\end{abstract}

\section{Keywords}

Abiotic stress, Agriculture, Phytohormones, Plant growth-promoting rhizobacteria, Siderophore

\section{Introduction}

Around 5.2 billion hectare of cultivable land are affected by various abiotic stresses such as drought, salinity and extreme temperature stresses $(1,2)$. Due to different stresses, plants undergo different physiological and morphological changes (3). In some plants, leaf growth is reduced due to high salinity and loss of water absorption capacity (4). Several studies on toxicity of heavy metals such as lead, cadmium, cobalt, arsenic were also studied (5, 6). These heavy metals are naturally occurring elements that have higher density than water. Plant needs certain metals in a limited amount for their growth, and some of the metal that is present in the soil mixes up with the soil particles and the remaining metal particles accumulate in the soil in high amounts that increases the toxicity in the soil. Metal toxicity also affects the function, activities and physiological state of plants.

Plant growth promoting rhizobacteria (PGPR) are the free-living soil bacteria and due to root exudates, they are capable of colonizing the rhizo- 
spheric region of plants. There are two major classes of rhizobacteria, intracellular PGPR (iPGPR) and extracellular PGPR (ePGPR) (7). In general, extracellular plant growth promoting bacteria exist in/on the rhizospheric region, rhizoplane and intracellular spaces in the root cortex while the intracellular plant growth promoting bacteria exists inside root cells generally called as nodular structures (8).

Many research have shown several benefits of PGPRs in improving plant growth and development (9). Under extreme environmental conditions, rhizospheric bacteria have been found to be beneficial for developing abiotic stress tolerance and crop improvement (10). Inoculation of PGPR strains to plants that are under high salinity alleviates the growth of the plant by tolerating such stresses. Strains like Pseudomonas putida improves drought stress tolerance in chickpea (Cicer arietinum), similarly other strains like Bacillus thuringiensis in soyabean results in modification in the root structure under water deficit conditions $(11,12)$. For eradication of heavy metals, metal resistant rhizobacteria can serve as an effective method for sequestering of heavy metal. Strains such as Kluyvera ascorbata showed high levels of heavy metal resistance and better seedlings growth under heavy metal stress. Other strains, such as P. putida and Azospirillum are characterized by the development of metal toxicity (8). PGPRs improve and increase the uptake of nutrients by plants from the soil $(13,14)$. Neutralizing plant stresses (both biotic and abiotic), an important effect of PGPR reduces or prevents the harmful effects of phyto-pathogenic organisms. PGPRs play important role in enhancing crop productivity through mechanism of phytostimulator, biofertilizer, biopesticides and rhizoremediation $(13,15,16)$.

PGPRs promote the growth of plant by enhancing the uptake of nutrient and improving the growth expansion and inducing the level of hormones in plants. They act either directly or indirectly to stimulate plant growth and enhance stress tolerance. Direct modes of action include nitrogen fixation, and production of phytohormones, thereby neutralizing various abiotic stresses. Indirect mechanisms prevent or suppress the negative effects on the plant that increase the natural resistance of the host. These mechanisms also help plants to thrive under environmental stresses or disease-based stress (17).

\section{Direct mechanism of PGPRs}

The direct mechanism facilitates the uptake of nutrients and/or increases the availability of nutrients through nitrogen fixation, production of phytohormones, and mineralization of soluble nutrients. The uptake of minerals increases due to the influx of ions in the root system. Studies over the last half century have found variants of PGPR, which have been used extensively so far, including the genera of Klebsiella, Pseudomonas, Azotobacter, Enterobacter, Variovorax, Bacillus, Azospirillum (18). These bacterial communities possess valuable and essential nutrient properties such as nitrogen and phosphorus for the plant growth. Using different crops and species of rhizobacteria various studies and formulations have been developed around the world (19).

\section{Mechanism of Nitrogen fixation}

Biological nitrogen fixation is accomplished through a non -symbiotic or symbiotic relationship between a host, pathogen and a plant. PGPR immobilizes atmospheric nitrogen in the soil and has a symbiotic relationship. Several studies have reported that inoculation with rhizosphere bacteria had shown to improve the soil quality and enhances nodule formation $(20,21)$. These nitrogen-fixing PGPR inoculants can increase the yield of cereal crops, maintain the level of nitrogen in cropland and improve stress tolerance and aid in disease management. The commercial inoculants Azospirillum produced are very effective in increasing the yield of crops worldwide (22). In legume rhizobacteria, the release of ammonia is part of their nitrogen fixation process. There are some C3 and C4 plants, such as wheat, maize, rice, cotton, sugar cane and Jatropha which are involved in interaction with some PGPR and contribute to the growth of grain yield and vegetative phase (23).

\section{Mechanism of phosphate-solubilizing bacteria}

Phosphate solubilizing bacteria (PSB) are ubiquitous and belong to the PGPR group and their properties allow rhizobacteria to dissolve phosphate in the soil $(15,24)$. There are various mechanisms used by PSB to convert insoluble phosphates to soluble form. The bacterial mechanism consists of dissolving organic phosphates in the soil by the action of acids such as gluconic acid that is being synthesized by soil bacteria $(25,26)$. The mineralization of phosphates is another important mechanism that is carried out by soil bacteria which synthesize extracellular phosphatase enzymes, such as phytases and nucleases to catalyze the hydrolysis of phosphoric esters, followed by release of the phosphate group (27). Solubilization and mineralization both occur in the same bacterial strain. Several bacteria which employ this mechanism to genera Azospirillum, Serratia, Azotobacter, Rhizobium, Burkholderia and Pseudomonas (28). The microorganisms involved in these three domains, include eukaryotes, bacteria and archaea. The important mechanisms for solubilizing inorganic phosphate are acidification, chelation, and enzymatic action. By secreting acidic and alkaline phosphatases, or by generating organic acids, they induce the mineralization of organic phosphates. Bacterial genera such as Burkholderia, Rhizobium, Bacillus, Natrinema, Serratia and Pseudomonas have been reported to be potent and effective phosphate solubilizers. The combination of plant growth promoting bacteria with phosphate solubilizers or phosphate solubilizer alone is helpful in improving the uptake of phosphate by crops, thus improving their yield due to environmental and agricultural sustainability (29).

\section{Mechanism of Phytohormone production}

Phytohormones are low molecular weight plant growth regulators that are produced at one site and are then transferred to different sites where they play an important role in promoting the growth and development of plants $(30,31)$. Many PGPRs induce the production of phytohormones and are involved in plant-microbe interaction and are responsible for root growth and architecture $(9,32)$. In rhizobacteria, Indole-3-acetic acid (IAA) is synthesized 
from tryptophan, involved in root growth and development and shoot meristem. In transgenic plants, endogenous cy(33). Some rhizobacterial strains produce gibberellins that tokinin overproduction induces diverse phenotypic alterainitiate plant shoot growth enhancement (34). Similarly, tions in vitro. The interaction of auxins and cytokinins leads there are other strains e.g. Pseudomonas stutzerl, Steno- to the control of various essential developmental processes trophomonas maltophilia and P. putida produce the plant in plants, mainly in the apical dominance and the develophormone cytokinins, which lead to the production of root ment of roots and shoots. In the case of in vitro, the major exudates, thereby increasing the availability of PGPR to regulator of organogenesis is the balance between auxin plants (30). Other PGPR produces hydrogen cyanide, that and cytokinin. In callus culture, a high auxin to cytokinin acts as biocontrol agent and has potential to inhibit the ratio initiates root formation, while a low ratio results in deleterious pathogen for e.g. Pseudomonas (35).

\section{Phytohormone: Auxin} shoot formation $(45,46)$.

\section{Phytohormone: Ethylene}

Auxin is one of the most important type of plant growth enhancer in the form of Indole-3-acetic acid (IAA) and Indole-3-butyric acid (IBA) and their precursors. The production of auxin by plants and microorganisms differs due to the biosynthetic pathway followed by them $(33,36)$. In general, bacterial species have the maximum capacity for auxin synthesis. The activity of auxins to act as growth promoters depends on bacterial and plant species. Some of the rhizosphere bacteria which can synthesize auxins includes Aeromonas punctata PNS-1, Serratia marcescens 90-166, Azospirillum brasilense Sp245, Pseudomomas putida, Pseudomomas moraviensis, Paenibacillus illinoisensis IB 1087 and Pseudomonas extremaustralis IB-K13-1A. Various studies have shown that IAA acts as a plant growth promoter and mutant such as super root and yucca producing IAA have long hypocotyls, more number of lateral root and root hairs, and also on growth of excised stem and hypocotyls and auxin analogs in intact Arabidopsis seedlings (37). The adventitious roots production derived from the stem is the effect of auxin induction (38).

\section{Phytohormone: Gibberellins}

Gibberellin is the largest group of plant hormones as over 100 different molecules of gibberellins with varying degrees of biological activity are known (39). Legumes are an important source of nitrogen fixation capable of producing gibberellins due to the presence of rhizobacteria within the nodule. When plants form nodules they require the presence of phytohormones such as auxin, cytokinin and small amounts of gibberellins (40). Bacillus licheniformis and $\mathrm{Ba}$ cillus pumilus are species of bacteria known for the production of gibberellins (41). This hormone has the property of translocation from the roots to the aerial part of the plant. The effectiveness of gibberellin is increased in combination with auxin by stimulating the root system, improving nutrient supply in the aerial part. Acetobacter diazotrophicus, Herbaspirillum seropedicae and Bacillus sp. have been confirmed in gibberellin production (42).

\section{Phytohormone: Cytokinin}

Some of the PGPR which synthesize cytokinin includes Pseudomonas stutzeri, Stenotrophomonas maltophilia and $P$. putida. Cytokinin is involved in the maintenance of plant cell division in culture and in various differentiation processes such as primary root growth, callus formation and shoot formation $(43,44)$. Totipotency is the distinguishing feature of cytokinin from other plant growth regulators, which helps to maintain totipotent stem cells in their root

Ethylene is a phytohormone that acts as a multifunctional regulator of plant growth. Depending on its time of application, concentration and plant species, it acts as a promoter and inhibitor to plant growth (47). The precursor of ethylene hormone is 1-aminocyclopropane-1-carboxylate (ACC), which is hydrolyzed by the enzyme ACC deaminase, generates ammonia and ketobutyrate. Under stress conditions like flood, and water scarcity, the amount of ethylene is high which tends to inhibit the growth of the plant and especially seedlings (48). ACC deaminase regulates the production of ethylene under stress conditions and promote plant growth by reducing harmful effects on plants (49). Many genera of the PGPRs have ACC deaminase activity which includes Aneurinibacillus, Arthrobacter, Achromobacter, Bacillus, Brevibacterium, Burkholderia, Citrobacter, Enterobacter, Leclercia, Micrococcus, Ochrobactrum, Parastrephia, Pseudomonas, Ralstonia and Serratia. These PGPRs mitigate the adverse effect of stress manifested on plants by minimizing the ethylene emission to its optimum level and thus confers growth promotion and stress tolerance in stressed plants (50).

\section{Phytohormone: Abscisic acid}

Abscisic acid (ABA) plays an important role in many physiological processes in plants. This hormone is necessary for regulation of several events during late seed development and is crucial for the response to environmental stresses such as desiccation, salt and cold. ABA acts like ethylene in stressed conditions and comes under the category of both plant growth promoter and inhibitor depending upon different conditions (51). Some of the species reported to induce ABA production in plants includes Bacillus megaterium, Azospirillum brasilense Sp 245, Bacillus licheniformis Rt4M10. Plant injected with A. brasilense Sp 245, B licheniformis Rt4M10 resulted increased ABA concentration and higher resistance against stressed condition (52).

\section{Exopolysaccharides production}

Exopolysaccharide (EPS) are extracellular carbohydrate polymer that are secreted by rhizobacteria (53). EPS works in two different ways, one by forming a capsule layer which is bound to the cell wall and the other by being released into surrounding cells such as extracellular slime layer. The synthesis of EPS is due to stress response (54). EPS performs various important activities such as plasma substitution and bioremediation, biofilm formation, gelling, antibacterial activity against predators and maintain the main cellular functions, the kinetics of reduction of contami- 
nants, the prevention of desiccation of bacterial cells. EPS producing bacteria are capable to maintain higher soil moisture content and growth of plants even under severely dried sandy soils (55-57).

\section{Mechanism of Siderophore production}

Siderophores are low molecular weight compound (4001500 Dalton) produced by bacteria and plants. Bacterial siderophore has been classified into 5 categories namely hydroxamates, catecholates, peptide siderophores, mycobactin and citrate hydroxamates (58). In aerobic environments, iron exists in an insoluble form, where it exists in the trivalent state as the oxyhydroxide (59). Iron in this trivalent state is sparingly soluble and therefore it is not available to microorganisms and plants, which need iron in the form of $\mathrm{Fe}^{+2}$. In response to this, microorganisms use a pathway to take up this essential nutrient. This pathway is involved in the production of accessory low molecular weight molecules with an abnormally excessive empathy for $\mathrm{Fe}^{+3}$. The bacteria that produce siderophores act as biocontrol agents (60). These siderophores helps the plants to take up $\mathrm{Fe}^{+2}$, where $\mathrm{Fe}^{+3}$ ion and a siderophore forms a complex in the membrane in which $\mathrm{Fe}^{+3}$ is reduced to $\mathrm{Fe}^{+2}$, which is released into the cell by the siderophore (17). There are over 500 siderophores known to date, which demonstrate the advantage of bacterial siderophores for plant growth (a) nutrient acquiring ability of sunflower plant under stress using Bacillus sporothermodurans (61), (b) reduction of heavy metal stress using siderophore producing Mesorhizobium sp. (62), during this reduction process siderophores can be destroyed or recycled. The siderophores release iron by reduction via ferric reductase, or by chemical modification or breakdown of the ferric siderophores complex by acetylation and esterase. They also prevent the phytopathogens from acquiring the appropriate amount of iron, thereby limiting their ability to proliferate.

\section{Indirect mechanism of PGPRs}

PGPRs exhibits indirect biocontrol mechanism to suppress disease caused by pathogens. The indirect mechanism includes the stimulation of plant growth and the induction of acquired systemic resistance. Biotic stress is often faced by the cultivated and native plants when they are infected by many pathogens like viroids, fungi, bacteria, viruses, nematodes, protists and insects, resulting in significant loss in the crop productivity (63). The fungi cause the maximum biotic stress to the plant. PGPR, such as Bacillus subtilis, Bacillus amyloliquefaciens strain HYD-B17, Paenibacillus polymyxa strains B2, B3, B4, B. licheniformis strain HYTAP$B 18$ and $B$. thuringiensis strains help in combating biotic stress conditions. Studies have shown that plants inoculated with such strains increase root structure under biological stress conditions (64).

\section{Hydrogen cyanide production}

Hydrogen cyanide ( $\mathrm{HCN}$ ) production is induced indirectly by the production of siderophores, lytic enzymes etc. Hydrogen cyanide functions as biocontrol agents, chelation of metals and it indirectly increases the availability of phos- phate (65). Bacteria, fungi, algae and plants produce $\mathrm{HCN}$, which is toxic to plants by colonizing the roots of plants and reduces their growth. When the host plant was introduced to a cyanide-producing strain, this host-specific rhizobacteria was used as a biological weed control agent, with no negative effects on the host plant (66). Another advantage is the secretion of a secondary metabolite that functions in weed control as a biological control. HCN can also induce cell death by inhibiting the energy supply of cell and electron transport chains. Bacillus and Pseudomonas species are species with an HCN production mechanism (66). The production and synthesis of HCN by PGPR are independent of their genus and their impact suggested their possibility to use as biological fertilizers or biocontrol to enhance crop production.

\section{Induced systemic resistance}

Induced systemic resistance (ISR) is an extensive phenomenon that has been studied and has potential to protect plants against any stresses and pathogens (67). The improved defensive capacity is a physiological state that responds to stimuli in the environment. In the case of local infection, ISR triggers cascades of signaling pathways, activation of certain genes, resulting in protection of plants $(67$, 68). Strains like, Serratia marcescens are helpful in plant growth and in inducing systemic resistance mechanisms to aid plant growth and to increase salt tolerance of wheat (69). Induced systemic resistance (ISR) is an indirect method of PGPR which is beneficial to plants by competing for production of parasitism, nutrient, metabolites and antibiotics. Systemic acquired resistance (SAR) is equivalent to ISR. This is because of induced systemic resistance, a resistance developed by PGPR and SAR is the resistance caused by the pathogen infection in plants.

\section{PGPR- the benefitting technology, future as- pects and scopes}

Bacteria have a variety of benefits that could be beneficial in commercial agriculture (70). Rhizobacteria and its beneficial strains have improved productivity and agricultural yields by virtue of its mechanism and mode of action (Table 1). The rhizobacteria not only acts as a biocontrol agent, but also in sustained maintenance, protecting plants and most importantly elicit positive effect on field conditions that were affected by stress conditions $(8,71)$.

Strategies have been developed using a PGPR preparation, so that the bacteria of interest benefit from colonization more than others. Under field conditions, inoculation improves product quality, stability and compatibility. Mechanisms of binding to PGPR as well as to plantassociated biofilm have been established for plant parts such as leaves, roots and seeds. This method has one advantage i.e. higher resistance to antibiotics, which improves the chances of crop survival under stressful soil conditions e.g. Pseudomonas, Azotobacter $(84,85)$. To promote microbial growth, Biochar (transport material for microbial inoculant) has the ability to increase crop yield, organic matter content, improving soil fertility by affecting the survival of microorganisms in the soil and maintaining nutri- 
Table 1. The uses of plant growth promoting rhizobacteria in improving the plant growth

\begin{tabular}{|c|c|c|c|}
\hline Plant/Host & PGPR & Uses & $\begin{array}{l}\text { Refer- } \\
\text { ences }\end{array}$ \\
\hline Vinca rosea & Bacillus megat Arium & Stress elevation Ni phytoextraction & $(72)$ \\
\hline Prosopis juliflora & Bacillus staphylococcus & Improves efficiency of phytoremediation & $(73)$ \\
\hline Oryza sativa & Agrobactum fabrum & Increased phytoremediation, decreased toxicity in soil & (74) \\
\hline Indian mustard & Kluyvera ascorbata & Decreased plant growth inhibition by heavy leaves & $(75)$ \\
\hline Glycine max & Bradyrhizobium japonicum & Excess in plant biomass, growth in high arsenic concentration & (76) \\
\hline Arabidopsis thaliana & Pseudomonas putida & Improves utilization of secondary metabolites & $(77)$ \\
\hline Azospirillum lipoferum & Triticum aestivum & Promote development of root system & (78) \\
\hline Azospirillum spp. & Zea mays & Increased growth under drought conditions & $(79)$ \\
\hline Bradyrhizobium japonicum & Zea mays & Synthesize IAA adequate to promote morphological changes and promote growth & (80) \\
\hline Enterobacter sp. & Oryza sativa & Promote seedling growth under salt stress & $(81)$ \\
\hline Bacillus subtilis & Brassica juncea & Facilitate nickel accumulation & $(82)$ \\
\hline
\end{tabular}

ents thereby preventing plants from resisting fungal preda- 2. Purty R, Sachar M, Chatterjee S. Structural and expression analytors $(86,87)$. sis of salinity stress responsive phosphoserine phosphatase from Brassica juncea L. J Proteomics Bioinform. 2017;10:119-27. https://doi.org/10.4172/jpb.1000432

The development of these methods along with the mode of action and/or mechanism of PGPR not only improves the growth of plants, but also increases the yield in the field with less use of fertilizer. For strains showing positive response are potential agents and bio stimulants (88, 89). The relationship between plants and pathogens has 4 been studied for over years. PGPRs that promote growth of plants are very promising in combating negative responses of crops under stress conditions. Thus, it is clear that PGPR has great potential in sustainable crop management and mainly focuses on stimulating plant growth especially under adverse conditions (90).

\section{Acknowledgements}

All authors acknowledge the GGS Indraprastha University, New Delhi for providing financial (FRGS Grant No. GGSIPU/ DRC/FRGS/2021/594/20).and infrastructure support. RSP also like to thanks SERB, DST India for financial support (Grant No. EEQ/2016/000166).

\section{Authors contributions}

NC, SC and RSP designed the study. VS, AS, DS, AS and SP wrote the initial manuscript. All authors read the edited manuscript for critical content and approved the final version of the manuscript.

\section{Compliance with ethical standards}

Conflict of interest: Authors do not have any conflict of interests to declare.

Ethical issues: None.

\section{References}

1. Roy R, Purty R, Agrawal V, Gupta S. Promoterless gus gene shows leaky $\beta$-glucuronidase activity during transformation of tomato with bspA gene for drought tolerance. Biologia Plantarum. 2006;50(3):352-58. http://dx.doi.org/10.1007/s10535-006-0049-6

3. Singh DK, Mehra S, Chatterjee S, Purty RS. In silico identification and validation of miRNA and their DIR specific targets in Oryza sativa Indica under abiotic stress. Non-coding RNA research. 2020;5(4):167-77. https://doi.org/10.1016/j.ncrna.2020.09.002

Waziri A, Chatterjee S, Purty RS. Expression analysis of OsPHD6 gene in response to salinity stress and rehydration in rice seedlings. Plant Cell Biotechnology and Molecular Biology. 2020:6574.

5. Gullap MK, Dasci M, Erkovan Hi, Koc A, Turan M. Plant growthpromoting rhizobacteria (PGPR) and phosphorus fertilizerassisted phytoextraction of toxic heavy metals from contaminated soils. Communications in Soil Science and Plant Analysis. 2014;45(19):2593-606.

https:// doi.org/10.1080/00103624.2014.929702

6. Bhati T, Gupta R, Yadav N, Singh R, Fuloria A, Waziri A. et al. Assessment of bioremediation potential of Cellulosimicrobium sp. for treatment of multiple heavy metals. Microbiology and Biotechnology Letters. 2019;47(2):269-77. https://doi.org/10.4014/ mbl.1808.08006

7. Rai PK, Singh M, Anand K, Saurabh S, Kaur T, Kour D et al. Role and potential applications of plant growth-promoting rhizobacteria for sustainable agriculture. New and Future Developments in Microbial Biotechnology and Bioengineering: Elsevier; 2020. p. 49-60. https://doi.org/10.1016/B978-0-12-820526-6.00004-X

8. Subiramani S, Ramalingam S, Muthu T, Nile SH, Venkidasamy B. Development of abiotic stress tolerance in crops by plant growth -promoting. Phyto-Microbiome in Stress Regulation. 2020:125. https://doi.org/10.1007/978-981-15-2576-6_8

9. Ahemad M, Kibret M. Mechanisms and applications of plant growth promoting rhizobacteria: current perspective. Journal of King Saud University-Science. 2014;26(1):1-20. https:// doi.org/10.1016/j.jksus.2013.05.001

10. Nivetha N, Lavanya A, Vikram K, Asha A, Sruthi K, Bandeppa S et al. PGPR-mediated regulation of antioxidants: Prospects for abiotic stress management in plants. Antioxidants in Plant-Microbe Interaction: Springer; 2021. p. 471-97. https:// doi.org/10.1007/978-981-16-1350-0_23

11. Kunert KJ, Vorster BJ, Fenta BA, Kibido T, Dionisio G, Foyer CH. Drought stress responses in soybean roots and nodules. Frontiers in Plant Science. 2016;7:1015. https://doi.org/10.3389/ fpls.2016.01015

12. Abdela AA, Barka GD, Degefu T. Co-inoculation effect of Mesorhizobium ciceri and Pseudomonas fluorescens on physiological and 
biochemical responses of Kabuli chickpea (Cicer arietinum L.) during drought stress. Plant Physiology Reports. 2020;25(2):35969. https://doi.org/10.1007/s40502-020-00511-x

13. Riaz U, Murtaza G, Anum W, Samreen T, Sarfraz M, Nazir MZ. Plant Growth-Promoting Rhizobacteria (PGPR) as biofertilizers and biopesticides. Microbiota and Biofertilizers: Springer; 2021. p. 181-96. https://doi.org/10.1007/978-3-030-48771-3_11

14. Egamberdieva D, Adesemoye AO. Improvement of crop protection and yield in hostile agroecological conditions with PGPRbased biofertilizer formulations. Bioformulations: For Sustainable Agriculture: Springer; 2016. p. 199-211. https:// doi.org/10.1007/978-81-322-2779-3_11

15. Ahemad M. Phosphate-solubilizing bacteria-assisted phytoremediation of metalliferous soils: a review. 3 Biotech. 2015;5(2):11121. https://doi.org/10.1007/s13205-014-0206-0

16. Mishra I, Arora NK. Rhizoremediation: a sustainable approach to improve the quality and productivity of polluted soils. Phyto and Rhizo Remediation: Springer; 2019. p. 33-66. https:// doi.org/10.1007/978-981-32-9664-0_2

17. Gouda S, Kerry RG, Das G, Paramithiotis S, Shin H-S, Patra JK. Revitalization of plant growth promoting rhizobacteria for sustainable development in agriculture. Microbiological Research. 2018;206:131-40. https://doi.org/10.1016/j.micres.2017.08.016

18. Mekonnen $\mathrm{H}$, Kibret $\mathrm{M}$. The roles of plant growth promoting rhizobacteria in sustainable vegetable production in Ethiopia. Chemical and Biological Technologies in Agriculture. 2021;8(1):111.https://doi.org/10.1186/s40538-021-00213-y

19. Backer R, Rokem JS, Ilangumaran G, Lamont J, Praslickova D, Ricci $\mathrm{E}$ et al. Plant growth-promoting rhizobacteria: context, mechanisms of action and roadmap to commercialization of biostimulants for sustainable agriculture. Frontiers in Plant Science. 2018;9:1473. https://doi.org/10.3389/fpls.2018.01473

20. Masson-Boivin C, Sachs JL. Symbiotic nitrogen fixation by rhizobia-the roots of a success story. Current Opinion in Plant Biology. 2018;44:7-15. https://doi.org/10.1016/j.pbi.2017.12.001

21. Son Y. Non-symbiotic nitrogen fixation in forest ecosystems. Ecological Research. 2001;16(2):183-96. https://doi.org/10.1046/ j.1440-1703.2001.00385.x

22. Fukami J, Cerezini P, Hungria M. Azospirillum: benefits that go far beyond biological nitrogen fixation. AMB Express. 2018;8(1):1-12. https://doi.org/10.1186/s13568-018-0608-1

23. Kennedy IR, Choudhury A, Kecskés ML. Non-symbiotic bacterial diazotrophs in crop-farming systems: can their potential for plant growth promotion be better exploited? Soil Biology and Biochemistry. 2004;36(8):1229-44. https://doi.org/10.1016/ j.soilbio.2004.04.006

24. Liu Z, Li YC, Zhang S, Fu Y, Fan X, Patel JS et al. Characterization of phosphate-solubilizing bacteria isolated from calcareous soils. Applied Soil Ecology. 2015;96:217-24. https://doi.org/10.1016/ j.apsoil.2015.08.003

25. Rodriguez H, Gonzalez T, Goire I, Bashan Y. Gluconic acid production and phosphate solubilization by the plant growthpromoting bacterium Azospirillum spp. Naturwissenschaften. 2004;91(11):552-55. https://doi.org/10.1007/s00114-004-0566-0

26. Alori ET, Glick BR, Babalola OO. Microbial phosphorus solubilization and its potential for use in sustainable agriculture. Frontiers in Microbiology. 2017;8:971. https://doi.org/10.3389/ fmicb.2017.00971

27. Sharma SB, Sayyed RZ, Trivedi MH, Gobi TA. Phosphate solubilizing microbes: sustainable approach for managing phosphorus deficiency in agricultural soils. SpringerPlus. 2013;2(1):1-14. https://doi.org/10.1186/2193-1801-2-587

28. Satyaprakash M, Nikitha T, Reddi E, Sadhana B, Vani SS. Phosphorous and phosphate solubilising bacteria and their role in plant nutrition. International Journal of Current Microbiology and Applied Sciences. 2017;6(4):2133-44. https:// doi.org/10.20546/ijcmas.2017.604.251

29. Divjot K, Rana KL, Tanvir K, Yadav N, Yadav AN, Kumar M et al. Biodiversity, current developments and potential biotechnological applications of phosphorus-solubilizing and-mobilizing microbes: A review. Pedosphere. 2021;31(1):43-75. https:// doi.org/10.1016/S1002-0160(20)60057-1

30. Maheshwari DK, Dheeman S, Agarwal M. Phytohormoneproducing PGPR for sustainable agriculture. Bacterial Metabolites in Sustainable Agroecosystem: Springer; 2015. p. 159-82. https://doi.org/10.1007/978-3-319-24654-3_7

31. Khan N, Bano A, Ali S, Babar MA. Crosstalk amongst phytohormones from planta and PGPR under biotic and abiotic stresses. Plant Growth Regulation. 2020;90(2):189-203. https:// doi.org/10.1007/s10725-020-00571-x

32. Vacheron J, Desbrosses G, Bouffaud M-L, Touraine B, MoënneLoccoz Y, Muller D et al. Plant growth-promoting rhizobacteria and root system functioning. Frontiers in Plant Science. 2013;4:356. https://doi.org/10.3389/fpls.2013.00356

33. Spaepen S, Vanderleyden J, Remans R. Indole-3-acetic acid in microbial and microorganism-plant signaling. FEMS Microbiology Reviews. 2007;31(4):425-48. https://doi.org/10.1111/j.15746976.2007.00072.x

34. Kang S-M, Waqas M, Khan AL, Lee I-J. Plant-growth-promoting rhizobacteria: potential candidates for gibberellins production and crop growth promotion. Use of Microbes for the Alleviation of Soil Stresses, Volume 1: Springer; 2014. p. 1-19. https:// doi.org/10.1007/978-1-4614-9466-9_1

35. Manasa K, Reddy RS, Triveni S, Kumar BK, Priya NG. Characterization of Rhizobium isolates and their potential PGPR characteristics of different rhizosphere soils of Telangana region, India. Int J Curr Microbiol Appl Sci. 2017;6(5):2808-13. https:// doi.org/10.20546/ijcmas.2017.605.316

36. Zhang P, Jin T, Kumar Sahu S, Xu J, Shi Q, Liu H et al. The distribution of tryptophan-dependent indole-3-acetic acid synthesis pathways in bacteria unraveled by large-scale genomic analysis. Molecules. 2019;24(7):1411. https://doi.org/10.3390/ molecules 24071411

37. Boerjan W, Cervera M-T, Delarue M, Beeckman T, Dewitte W, Bellini C et al. Superroot, a recessive mutation in Arabidopsis, confers auxin over production. The Plant Cell. 1995;7(9):1405-19. https://doi.org/10.1105/tpc.7.9.1405

38. Savaldi-Goldstein S, Baiga TJ, Pojer F, Dabi T, Butterfield C, Parry $\mathrm{G}$ et al. New auxin analogs with growth-promoting effects in intact plants reveal a chemical strategy to improve hormone delivery. In: Proceedings of the National Academy of Sciences. 2008;105(39):15190-95. https://doi.org/10.1073/pnas.0806324105

39. Egamberdieva D, Wirth SJ, Alqarawi AA, Abd_Allah EF, Hashem A. Phytohormones and beneficial microbes: essential components for plants to balance stress and fitness. Frontiers in Microbiology. 2017;8:2104. https://doi.org/10.3389/fmicb.2017.02104

40. Ferguson BJ, Ross JJ, Reid JB. Nodulation phenotypes of gibberellin and brassinosteroid mutants of pea. Plant Physiology. 2005;138(4):2396-405. https://doi.org/10.1104/pp.105.062414

41. Gutiérrez-Mañero FJ, Ramos-Solano B, Probanza An, Mehouachi J, R. Tadeo F, Talon M. The plant-growth-promoting rhizobacteria Bacillus pumilus and Bacillus licheniformis produce high amounts of physiologically active gibberellins. Physiologia Plantarum. 2001;111(2):206-11. https://doi.org/10.1034/j.13993054.2001.1110211.x

42. Joo G-J, Kim Y-M, Lee I-J, Song K-S, Rhee I-K. Growth promotion of red pepper plug seedlings and the production of gibberellins by Bacillus cereus, Bacillus macroides and Bacillus pumilus. Bio- 
technology letters. 2004;26(6):487-91. https://doi.org/10.1023/ B:BILE.0000019555.87121.34

43. Werner T, Motyka V, Strnad M, Schmülling T. Regulation of plant growth by cytokinin. In: Proceedings of the National Academy of Sciences. 2001;98(18):10487-92. https://doi.org/10.1073/ pnas. 171304098

44. Wu W, Du K, Kang X, Wei H. The diverse roles of cytokinins in regulating leaf development. Horticulture Research. 2021;8(1):113. https://doi.org/10.1038/s41438-021-00558-3

45. Hussain S, Nanda S, Zhang J, Rehmani MIA, Suleman M, Li G et al. Auxin and cytokinin interplay during leaf morphogenesis and phyllotaxy. Plants. 2021;10(8):1732. https://doi.org/10.3390/ plants 10081732

46. Su Y-H, Liu Y-B, Zhang X-S. Auxin-cytokinin interaction regulates meristem development. Molecular plant. 2011;4(4):616-25. https://doi.org/10.1093/mp/ssr007

47. Iqbal N, Khan NA, Ferrante A, Trivellini A, Francini A, Khan M. Ethylene role in plant growth, development and senescence: interaction with other phytohormones. Frontiers in Plant Science. 2017;8:475. https://doi.org/10.3389/fpls.2017.00475

48. Schaller GE. Ethylene and the regulation of plant development. BMC Biology. 2012;10(1):1-3. https://doi.org/10.1186/1741-700710-9

49. Bal HB, Nayak L, Das S, Adhya TK. Isolation of ACC deaminase producing PGPR from rice rhizosphere and evaluating their plant growth promoting activity under salt stress. Plant and Soil. 2013;366(1):93-105. https://doi.org/10.1007/s11104-012-1402-5

50. Nazli F, Mustafa A, Ahmad M, Hussain A, Jamil M, Wang X et al. A review on practical application and potentials of phytohormoneproducing plant growth-promoting rhizobacteria for inducing heavy metal tolerance in crops. Sustainability. 2020;12(21):9056. https://doi.org/10.3390/su12219056

51. Purty R, Agrawal V, Gupta S. Induction of a novel boiling stable protein in response to desiccation and ABA treatments in Sesbania sesban var. bicolor leaves. Biologia Plantarum. 2005;49 (1):137. https://doi.org/10.1007/s00000-005-7140-1

52. Cohen AC, Bottini R, Pontin M, Berli FJ, Moreno D, Boccanlandro $\mathrm{H}$ et al. Azospirillum brasilense ameliorates the response of Arabidopsis thaliana to drought mainly via enhancement of ABA levels. Physiologia Plantarum. 2015;153(1):79-90. https:// doi.org/10.1111/ppl.12221

53. Costa OY, Raaijmakers JM, Kuramae EE. Microbial extracellular polymeric substances: ecological function and impact on soil aggregation. Frontiers in Microbiology. 2018;9:1636. https:// doi.org/10.3389/fmicb.2018.01636

54. Seesuriyachan $P$, Kuntiya A, Hanmoungjai $P$, Techapun C, Chaiyaso T, Leksawasdi N. Optimization of exopolysaccharide overproduction by Lactobacillus confusus in solid state fermentation under high salinity stress. Bioscience, Biotechnology and Biochemistry. 2012:110905. https://doi.org/10.1271/bbb.110905

55. Liu J, Wang X, Pu H, Liu S, Kan J, Jin C. Recent advances in endophytic exopolysaccharides: Production, structural characterization, physiological role and biological activity. Carbohydrate Polymers. 2017;157:1113-24. https://doi.org/10.1016/ j.carbpol.2016.10.084

56. Abdalla AK, Ayyash MM, Olaimat AN, Osaili TM, Al-Nabulsi AA, Shah NP et al. Exopolysaccharides as Antimicrobial Agents: Mechanism and Spectrum of Activity. Frontiers in Microbiology. 2021;12. https://doi.org/10.3389/fmicb.2021.664395

57. Naseem H, Ahsan M, Shahid MA, Khan N. Exopolysaccharides producing rhizobacteria and their role in plant growth and drought tolerance. Journal of Basic Microbiology. 2018;58 (12):1009-22. https://doi.org/10.1002/jobm.201800309
58. Rane M, Naphade B, Sayyed R, Chincholkar S. Methods for microbial iron chelator (siderophore) analysis. Basic and applied research in mycorrhizae IK International Publication, New Delhi, India. 2005:475-92.

59. Beneduzi A, Ambrosini A, Passaglia LM. Plant growth-promoting rhizobacteria (PGPR): their potential as antagonists and biocontrol agents. Genetics and Mlecular Biology. 2012;35:1044-51. https://doi.org/10.1590/S1415-47572012000600020

60. Kumar V, Singh S, Upadhyay N. Effects of organophosphate pesticides on siderophore producing soil microorganisms. Biocatalysis and Agricultural Biotechnology. 2019;21:101359. https:// doi.org/10.1016/j.bcab.2019.101359

61. Pourbabaee AA, shoaibi F, Emami S, Alikhani HA. The potential contribution of siderophore producing bacteria on growth and Fe ion concentration of sunflower (Helianthus annuus L.) under water stress. Journal of Plant Nutrition. 2018;41(5):619-26. https://doi.org/10.1080/01904167.2017.1406112

62. Huo Y, Kang JP, Ahn JC, Kim YJ, Piao CH, Yang DU et al. Siderophore-producing rhizobacteria reduce heavy metal-induced oxidative stress in Panax ginseng Meyer. Journal of Ginseng Research. 2021;45(2):218-27. https://doi.org/10.1016/ j.jgr.2019.12.008

63. Kumar A, Patel JS, Meena VS, Srivastava R. Recent advances of PGPR based approaches for stress tolerance in plants for sustainable agriculture. Biocatalysis and Agricultural Biotechnology. 2019;20:101271. https://doi.org/10.1016/j.bcab.2019.101271

64. Ngumbi E, Kloepper J. Bacterial-mediated drought tolerance: current and future prospects. Applied Soil Ecology. 2016;105:10925. https://doi.org/10.1016/j.apsoil.2016.04.009

65. Rijavec T, Lapanje A. Hydrogen cyanide in the rhizosphere: not suppressing plant pathogens, but rather regulating availability of phosphate. Frontiers in Microbiology. 2016;7:1785. https:// doi.org/10.3389/fmicb.2016.01785

66. Abd El-Rahman A, Shaheen HA, Abd El-Aziz RM, Ibrahim DS. Influence of hydrogen cyanide-producing rhizobacteria in controlling the crown gall and root-knot nematode, Meloidogyne incognita. Egyptian Journal of Biological Pest Control. 2019;29(1):1-11. https://doi.org/10.1186/s41938-019-0143-7

67. Annapurna K, Kumar A, Kumar LV, Govindasamy V, Bose P, Ramadoss D. PGPR-induced systemic resistance (ISR) in plant disease management. Bacteria in Agrobiology: Disease Management: Springer; 2013. p. 405-25. https://doi.org/10.1007/978-3642-33639-3_15

68. Rashid M, Chung YR. Induction of systemic resistance against insect herbivores in plants by beneficial soil microbes. Frontiers in Plant Science. 2017;8:1816. https://doi.org/10.3389/ fpls.2017.01816

69. Singh RP, Jha PN. The multifarious PGPR Serratia marcescens CDP-13 augments induced systemic resistance and enhanced salinity tolerance of wheat (Triticum aestivum L.). PLos one. 2016;11(6):e0155026. journal.pone.0155026

https://doi.org/10.1371/

70. Tabassum B, Khan A, Tariq M, Ramzan M, Khan MSI, Shahid N et al. Bottlenecks in commercialisation and future prospects of PGPR. Applied Soil Ecology. 2017;121:102-17. https:// doi.org/10.1016/j.apsoil.2017.09.030

71. Pahari A, Pradhan A, Nayak SK, Mishra B. Plant growth promoting rhizobacteria (PGPR): prospects and application. Frontiers in Soil and Environmental Microbiology: CRC Press; 2020. p. 47-56. https://doi.org/10.1201/9780429485794-5

72. Khan WU, Ahmad SR, Yasin NA, Ali A, Ahmad A, Akram W. Application of Bacillus megaterium MCR-8 improved phytoextraction and stress alleviation of nickel in Vinca rosea. International Journal of Phytoremediation. 2017;19(9):813-24. https:// doi.org/10.1080/15226514.2017.1290580 
73. Ramírez V, Baez A, López P, Bustillos R, Villalobos MÁ, Carreño R et al. Chromium hyper-tolerant Bacillus sp. MH778713 assists phytoremediation of heavy metals by mesquite trees (Prosopis laevigata). Frontiers in Microbiology. 2019;10:1833. https:// doi.org/10.3389/fmicb.2019.01833

74. Zafar-ul-Hye M, Shahjahan A, Danish S, Abid M, Qayyum MF. Mitigation of cadmium toxicity induced stress in wheat by ACCdeaminase containing PGPR isolated from cadmium polluted wheat rhizosphere. Pak J Bot. 2018;50(5):1727-34.

75. Kabiraj A, Majhi K, Halder U, Let M, Bandopadhyay R. Role of Plant Growth-Promoting Rhizobacteria (PGPR) for crop stress management. Sustainable Agriculture in the Era of Climate Change: Springer; 2020. p. 367-89. https://doi.org/10.1007/978-3030-45669-6_17

76. Bianucci E, Godoy A, Furlan A, Peralta JM, Hernández LE, Carpena-Ruiz RO et al. Arsenic toxicity in soybean alleviated by a symbiotic species of Bradyrhizobium. Symbiosis. 2018;74(3):16776. https://doi.org/10.1007/s13199-017-0499-y

77. Singh SK, Singh PP, Gupta A, Singh AK, Keshri J. Tolerance of heavy metal toxicity using PGPR strains of Pseudomonas species. PGPR Amelioration in Sustainable Agriculture: Elsevier; 2019. p. 239-52. https://doi.org/10.1016/B978-0-12-815879-1.00012-4

78. Ardakani MR, Mazaheri D, Mafakheri S, Moghaddam A. Absorption efficiency of $\mathrm{N}, \mathrm{P}, \mathrm{K}$ through triple inoculation of wheat (Triticum aestivum L.) by Azospirillum brasilense, Streptomyces sp., Glomus intraradices and manure application. Physiology and Molecular Biology of Plants. 2011;17(2):181-92. https:// doi.org/10.1007/s12298-011-0065-7

79. Shahzad A, Fahad S, Bano A, Siddiqui S, Qin M, Shakoor A. Bacterial consortium for improved maize production under oily sludge. Agronomy Journal. 2020;112(6):4634-47. https:// doi.org/10.1002/agj2.20339

80. Ghosh PK, Kumar De T, Maiti TK. Production and metabolism of indole acetic acid in root nodules and symbiont (Rhizobium undicola) isolated from root nodule of aquatic medicinal legume Neptunia oleracea Lour. Journal of Botany. 2015;2015. https:// doi.org/10.1155/2015/575067

81. Sarkar A, Ghosh PK, Pramanik K, Mitra S, Soren T, Pandey S et al. A halotolerant Enterobacter sp. displaying ACC deaminase activity promotes rice seedling growth under salt stress. Research in Microbiology. 2018;169(1):20-32. https://doi.org/10.1016/ j.resmic.2017.08.005
82. Rathore S, Shekhawat K, Dass A, Kandpal B, Singh V. Phytoremediation mechanism in Indian mustard (Brassicajuncea) and its enhancement through agronomic interventions. In: Proceedings of the National Academy of Sciences, India Section B: Biological Sciences. 2019;89(2):419-27. https://doi.org/10.1007/s40011-0170885-5

83. Mokrani S, Rai A, Belabid L, Cherif A, Cherif H, Mahjoubi M et al. Pseudomonas diversity in western Algeria: role in the stimulation of bean germination and common bean blight biocontrol. European Journal of Plant Pathology. 2019;153(2):397-415. https:// doi.org/10.1007/s10658-018-1566-9

84. Chennappa G, Sreenivasa M, Nagaraja H. Azotobacter salinestris: a novel pesticide-degrading and prominent biocontrol PGPR bacteria. Microorganisms for Green Revolution: Springer; 2018. p. 23-43. https://doi.org/10.1007/978-981-10-7146-1_2

85. Panpatte DG, Jhala YK, Shelat HN, Vyas RV. Pseudomonas fluorescens: a promising biocontrol agent and PGPR for sustainable agriculture. Microbial Inoculants in Sustainable Agricultural Productivity: Springer; 2016. p. 257-70. https:// doi.org/10.1007/978-81-322-2647-5_15

86. Ijaz M, Tahir M, Shahid M, Ul-Allah S, Sattar A, Sher A et al. Combined application of biochar and PGPR consortia for sustainable production of wheat under semiarid conditions with a reduced dose of synthetic fertilizer. Brazilian Journal of Microbiology. 2019;50(2):449-58. https://doi.org/10.1007/s42770-019-00043-z

87. Ren H, Huang B, Fernández-García V, Miesel J, Yan L, Lv C. Biochar and rhizobacteria amendments improve several soil properties and bacterial diversity. Microorganisms. 2020;8(4):502. https://doi.org/10.3390/microorganisms8040502

88. Rouphael Y, Colla G. Synergistic biostimulatory action: Designing the next generation of plant biostimulants for sustainable agriculture. Frontiers in Plant Science. 2018;9:1655. https:// doi.org/10.3389/fpls.2018.01655

89. Rouphael Y, Colla G. Biostimulants in agriculture. Frontiers in Plant Science. 2020;11:40. https://doi.org/10.3389/ fpls.2020.00040

90. Etesami H, Adl SM. Plant growth-promoting rhizobacteria (PGPR) and their action mechanisms in availability of nutrients to plants. Phyto-Microbiome in Stress Regulation. 2020:147-203. https:// doi.org/10.1007/978-981-15-2576-6_9 